\title{
SEISMIC-REFLECTION PROFILING OF A WIDESPREAD TILL BENEATH ICE STREAM B, WEST ANTARCTICA \\ (Abstract)
}

by

Sean T. Rooney, D.D. Blankenship, R.B. Alley and C.R. Bentley

(University of Wisconsin-Madison, Geophysical and Polar Research Center, 1215 W. Dayton Street, Madison, WI 53706-1692, U.S.A.)

\section{ABSTRACT}

Seismic-reflection profiling has previously shown that, at least at one location, Ice Stream B in West Antarctica rests on a layer of till a few meters thick (Blankenship and others 1986). Analyses of both compressional- and shear-wave seismic reflections from the ice-till boundary confirm the results of those earlier studies, which showed that the till is water-saturated and has a high porosity and low differential pressure. We conclude that this till is basically homogeneous, at least on a scale of tens of kilometers, though some evidence that its properties vary laterally can be discerned in these data. We propose that the till is widespread beneath Ice Stream B and probably also beneath the other West Antarctic ice streams.

Our seismic profiling shows that the till is essentially continuous beneath Ice Stream B over at least $12 \mathrm{~km}$ parallel to ice flow and $8 \mathrm{~km}$ transverse to flow. Beneath these profiles the till averages about $6.5 \mathrm{~m}$ thick and is present everywhere except possibly on isolated bedrock ridges parallel to ice flow. The till thickness on these bedrock ridges falls to less than $2 \mathrm{~m}$, the limit of our seismic resolution, but there is evidence that the ridges do not impede ice flow substantially. The bedrock beneath the till is fluted parallel to flow, with flutes that are $10-13 \mathrm{~m}$ deep by $200-1000 \mathrm{~m}$ wide; we believe these flutes are formed by erosion beneath a deforming till. We also observe an angular unconformity at the base of the till, which is consistent with the idea that erosion is occurring there. The sedimentary record in the Ross Embayment looks very similar to that beneath Ice Stream B, i.e. a few meters of till resting unconformably (the Ross Sea unconformity) on lithified sedimentary rock, and we postulate that the Ross Sea unconformity was generated by erosion beneath a grounded ice sheet by a deforming till.

\section{REFERENCE}

Blankenship, D.D., C.R. Bentley, S.T. Rooney, and R.B. Alley. 1986. Seismic measurements reveal a saturated porous layer beneath an active Antarctic ice stream. Nature, 322(6074), 54-57.

\section{FORCE BUDGET: NUMERICAL METHODS AND APPLICATION TO TWO-DIMENSIONAL FLOW ALONG THE BYRD STATION STRAIN NETWORK, WEST ANTARCTICA}

\author{
(Abstract) \\ by \\ C.J. van der Veen $*$ and I.M. Whillans***
}

(* Byrd Polar Research Center and ** Department of Geology and Mineralogy,

125 South Oval Mall, The Ohio State University, Columbus, OH 43210, U.S.A.)

\begin{abstract}
Using the partitioning of full stresses into resistive and lithostatic parts, force balance for plane flow is expressed in terms of strain-rates and a vertical coordinate scaled to the ice thickness. The balance equation and constitutive relation can then be used to calculate stresses through a vertical section of a glacier. Because the flow law is highly non-linear, these calculations are done numerically. Starting at the surface, the force-balance equation is solved by using measured surface velocities to calculate vertical shearing, and this yields velocities at a depth just below the surface. These velocities are used to compute vertical shearing at that depth, from which velocities at the next deeper layer follow. In this way, going progressively downward, velocities
\end{abstract}

and stresses are calculated throughout a section of a glacier.

The theory for calculating resistive stresses and velocities in a glacier is applied to the Byrd Station Strain Network. Large longitudinal variations in basal drag and in sliding velocity occur and this result is little affected by errors in the input data or by uncertainties in the constitutive relation for ice. The basal drag is usually equal to the driving stress to within $10-20 \%$, and both vary by a factor of about 2 along the strain network. Sites of high drag and little sliding are not always correlated with basal highs, indicating that some process (for example, complex bed drainage) is controlling the friction at the bed of the West Antarctic ice sheet. 